\title{
PERAN PEMERINTAH DAERAH DALAM PEMBERDAYAAN MASYARAKAT PETANI JAGUNG DI KECAMATAN BIRINGBULU KABUPATEN GOWA
}

\author{
Muh Nurdin ${ }^{1}$, St Nurmaeta ${ }^{1}$, Muhammad Tahir ${ }^{2}$ \\ ${ }^{1}$ Program Studi Ilmu Pemerintahan Fakultas Ilmu Sosial dan Ilmu Politik \\ Universitas Muhammadiyah Makassar \\ Jl Sultan Alauddin No 259 Makassar 90221 \\ Telp. 0411-866972 ext. 107. Fax. 0411-8655888 \\ nurdin01@yahoo.co.id nurmaetast@gmail.com \\ 2 Program Studi Ilmu Adminitrasi Negara Fakultas Ilmu Sosial dan Ilmu Politik \\ Universitas Muhammadiyah Makassar \\ Jl Sultan Alauddin No 259 Makassar 90221 \\ Telp. 0411-866972 ext. 107. Fax. 0411-8655888 \\ muh_tahir@gmail.com,
}

\begin{abstract}
The purpose of this study to determine the role of local government in community empowerment Biringbulu corn farmers in the District of Gowa. This type of research used was descriptive research and data analysis is the analysis of qualitative data. Data collection techniques used are observation, interviews and documentation. The results showed that: The role of local government in empowering communities corn farmers are already well underway; FeAs already carry corn farmer training went well, but not maximized in because there are many farmer groups have not received training; and local governments to provide assistance for seeds, fertilizers as well as savings and loan assistance.

Keywords: local government, empowerment, corn farmers

ABSTRAK

Tujuan penelitian ini untuk mengetahui peran Pemerintah Daerah dalam pemberdayaan masyarakat petani jagung di Kecamatan Biringbulu Kabupaten Gowa. Jenis penelitian yang di gunakan adalah penelitian deskriptif dan analisis data adalah analisis data kualitatif. Teknik pengumpulan data yang di gunakan yaitu observasi, wawancara dan dokumentasi. Hasil penelitian menunjukkan bahwa: Peran pemerintah daerah dalam pemberdayaan masyarakat petani jagung sudah berjalan dengan baik; penyuluh lapangan sudah melaksanakan pelatihan petani jagung berjalan dengan baik, akan tetapi belum maksimal di karenakan masih banyak kelompok tani belum mendapatkan pelatihan; dan pemerintah daerah memberikan bantuan bibit, pupuk serta bantuan simpan pinjam.
\end{abstract}

Kata Kunci : pemerintah daerah, pemberdayaan, petani jagung. 


\section{A. PENDAHULUAN}

Pemberdayaan masyarakat adalah upaya pemberian daya atau peningkatan keberdayaan. Pemberdayaan masyarakat dapat diartikan sebagai upaya untuk memandirikan masyarakat agar mampu berpartisipasi aktif dalam segala aspek pembangunan. Kemandirian buka berarti mampu hidup sendiri tetapi mandiri dalam pengambilan keputusan, yaitu memiliki kemampuan untuk memilih dan keberanian menolak segala bentuk bantuan dan atau kerjasama yang tidak menguntungkan. Dengan pemahaman seperti itu, pemberdayaan dapat diartikan sebagai proses terencana guna meningkatkan skala/upgrade utilitas dari obyek yang diberdayakan. Karena itu pemberdayaan masyarakat merupakan upaya untuk terus menerus meningkatkan harkat dan martabat lapisan masyarakat bawah yang tidak mampu melepaskan diri dari perangkap kemiskinan dan keterbelakangan. Dalam pengertian sehari hari, pemberdayaan masyarakat selalu dikonotasikan sebagai pemberdayaan masyarakat kelas bawah (grassroots) yang umumnya dinilai tidak berdaya.

Secara ekonomis, kemiskinan juga dapat diartikan sebagai kekurangan sumberdaya yang dapat digunakan untuk meningkatkan kesejehtaraan sekelompok orang. Kemiskinan memberi gambaran situasi serba kekurangan seperti terbatasnya modal yang dimiliki, rendahnya pengetahuan dan keterampilan, rendahnya produktivitas, rendahnya pendapatan, lemahnya nilai tukar hasil produksi orang miskin dan terbatasnya kesempatanberperan serta dalam pembangunan Kemiskinan antara lain ditandai oleh: (1) Sikap dan tingkah laku yang menerima keadaan yang seakan tak dapat diubah, yang tercermin di dalam lemahnya kemauan untuk maju, (2) Rendahnya kualitas sumberdaya manusia, (3) Lemahnya nilai tukar hasil produksi, (4) Rendahnya produktivitas, (5) Terbatasnya modal yang dimiliki, (6) Rendahnya pendapatan, (7) Terbatasnya kesempatan berpartisipasi dalam pembangunan.

Potensi sumber daya yang berasal dari sektor pertanian menjadi penting untuk disusun strategi pembangunan, sebab potensi sektor pertanian khususnya petani jagung menjadi prioritas penting seiring dengan makin meningkatnya konsumsi hasil produk pertanian. Untuk dapat meningkatkan hasil pertanian berdasar potensi yang dimiliki daerah diperlukan dukungan dana dan personil yang mampu memberikan pemahaman kepada produsen produk pertanian terkait proses hingga pasca produksi hasil pertanian. Rendahnya hasil produksi pertanian serta kurang diperhatikannya pasca produksi diperkirakan menjadi kendala dalam meningkatkan hasil pertanian pada daerah-daerah. Peran aparatur tingkat daerah perlu dibangun melalui peningkatan kapasitas atau kemampuan pemahaman semenjak produksi hingga pasca produksi hasil pertanian. Disamping itu, alokasi sumber dana yang mendukung terjaminnya sarana prasarana penunjang kegiatan pertanian diduga tidak sesuai dengan harapan dan kebutuhan. Sektor pertanian baik formal maupun informal khususnya di daerah perdesaan seharusnya memegang peranan penting dalam meningkatkan kualitas sumber daya manusia, peningkatan produksi dan pendapatan serta kesejahteraan petani jagung. Namun kinerjanya belum optimal yang dicirikan oleh masih sulitnya akses petani terhadap pelayanan lembaga-lembaga yang ada termasuk akses pemasaran. Akibatnya produktivitas pertanian dan pendapatan petani relatif masih rendah. Untuk meningkatkan peran sektor pertanian maka diperlukan pembinaan oleh 
pemerintah pusat maupun pemerintah daerah namun tanpa harus menciptakan kebergantungan pada pemerintah. Untuk dapat mendorong kinerja sektor pertanian, pemerintah daerah diharapkan mampu meningkatkan kemampuan atau kapasitas berbagai sumber daya yang dimiliki.

Sejalan dengan reformasi maka perhatian pemerintah, pada sektor pertanian, khususnya pada pertanian jagung mendapat prioritas utama dalam pembangunan sekarang ini disebabkan karena semakin tingginya harga hasil pertanian khusus petani jagung di seluruh Indonesia yang tidak dibarengi dengan pengetahuan para petani mulai dari pruduksi sampai pada pasca produksi , di samping itu mahalnya harga hasil pertanian tersebut di pasaran , kurangnya modal yang di miliki diyakini akibat lemahnya perlindungan pemerintah terhadap petani jagung khususnya. Hal ini disebabkan, lambatnya pemerintah dan DPR dalam menyelesaikan RUU Perlindungan dan Pemberdayaan Petani.

Diharapkan peran dari pemerintah daerah baik pemerintah Provinsi maupun pemerintah Kabupaten dalam hal ini adalah Kabupaten Gowa dalam rangka pemberdayakan masyarakat petani jagung yang ada di daerahnya. Kabupaten Gowa khusus Kecamatan Biringbulu merupakan daerah yang sangat kaya dengan sumber daya alam akan tetapi tidak diimbangi dengan sumber daya manusianya khususnya di bidang pertanian dan kurangnya modal yang di miliki sehingga sangat dibutuhkan peran pemerintah baik pemerintah sebagai fasilitator, dinamisator, regulator dan katalisator untuk mengembangkan sumber daya manusia di Kabupaten Gowa. Pemberdayaan masyarakat Indonesia khususnya petani jagung di Kabupaten Gowa harus menjadi perhatian lebih serius, terencana, terpadu, dan berkesinambungan, serta dipercepat prosesnya. Jika kita semua komitmen terhadap Undang-undang nomor 19 tahun 2013 tentang Pemberdayaan Petani.

Berdasarkan uraian di atas, maka penulis merencanakan penelitian mengenai peran pemerintah Daerah dalam pemberdayakan masyarakat petani jagung.

\section{B. KONSEP PERAN DAN PEMERINTAH DAERAH}

Mengenai pengertian peranan maka akan ditemukan bermacam-macam pendapat yang memberikan rumusanrumusan dan berbagai sudut pandang yang sangat bervariasi. Pariata Westra dalam Tuti (2003:9) mengatakan bahwa peranan adalah dapat diartikan sebagai terlaksananya suatu fungsi atau tugas tentang sesuatu hal tertentu untuk mencapai tujuan yang telah ditentukan.

Pengertian yang lain dikemukakan oleh Mayor Palak (Tuti, 2003:9) yang berpendapat bahwa: "Peranan atau role adalah suatu kelakuan yang diharapkan dari oknum dalam antar hubungan sosial tertentu yang berhubungan dengan status sosial tertentu".

Untuk menjalankan tugas negara sehari-hari, maka dibentuklah pemerintah. Pemerintah sebagai personifikasi negara berupaya sedapat mungkin untuk mewujudkan tugas dan tujuan negara menjadi kenyataan dan sebagai personifikasi atau alat pemerintah adalah birokrasi pemerintah sebagai pelaksana jabatan karier.

Birokrasi pemerintah di tingkat pusat disebut kementerian Negara beserta jajarannya yang membantu fungsi kekuasaan eksekutif yaitu presiden sebagai kepala negara dan kepalah pemerintahan. Yang mewujudkan fungsi eksekutif sehari-hari adalah birokrasi pemerintah, sehingga peranan birokrasi menjadi penting. Hal 
tersebut sesuai dengan apa yang dikemukakan oleh Thoha dalam Sembiring (2012:1), bahwa: peran birokrasi menjadi mengemuka karena didalam masyarakat sudah berkembang penguasa-penguasa politik yang telah mendelegasikan urusan-urusan perencanaan dan pelaksananan kebijakan pada birokrasi dan bahkan mengantunkannya pada infrastruktur birokrasi. Oleh karena posisisnya yang strategis dan mempunyai keahlian profesonal dalam fungsinya, serta mekanisme perencanaan dan pelaksanaan kebijakan erat sekali, maka peranan birokrasi dalam "public policy" sangat penting.

$\begin{array}{cc}\text { Pemerintahan pada } & \text { akhir } \\ \text { uraiannya, } & \text { adalah }\end{array}$
pengorganisasian kekuatan, tidak selalu berhubungan dengan organisasi kekuatan angkatan bersenjata, tetapi dua atau sekelompok orang dari sekian banyak kelompok. Orang yang dipersiapkan oleh suatu organisasi untuk mewujudkan maksud-maksud bersama mereka, dengan hal-hal yang memberikan keterangan bagi urusanurusan umum kemasyarakatan.

Pemerintah itu merupakan satuan anggota yang paling umum yang (a) memiliki tanggung jawab tertentu untuk mempertahankan sistem yang mencakupnya, itu adalah bagian dan (b) monopoli praktis mengenai kekuasaan paksaan. (Inu Kencana,2011:8,12).

Sebagaimana yang kita ketahui bersama dalam studi ilmu politik gejala pemerintahan merupakan bagian yang tak terpisahkan dari usaran kekuasaan.

$$
\text { Menurut Arif (2012) Peran }
$$
pemerintah daerah dalam pembinaan masyarakat yaitu terbagi menjadi empat peran yaitu:

a) Peran pemerintah sebagai regulator

$$
\text { Peran Pemerintah sebagai }
$$

Regulator adalah menyiapkan arah untuk menyeimbangkan penyelenggaraan pembangunan (menerbitkan peraturanperaturan dalam rangka efektifitas dan tertib administrasi pembangunan). Sebagai regulator, pemerintah memberikan acuan dasar yang selanjutnya diterjemahkan oleh masyarakat sebagai instrumen untuk mengatur setiap kegiatan pelaksanaan pemberdayaan dimasyarakat. Pemberdayaan masyarakat dari segi ekonomi akan dikaitkan dengan kebijakan yang mendukung dalam pengembangan usahanya.

b) Pemerintah sebagai dinamisator

Pemerintah sebagai dinamisator adalah menggerakan partisipasi multi pihak tatkala stagnasi terjadi dalam proses pembangunan (mendorong dan memelihara dinamika pembangunan daerah). Sebagai dinamisator, pemerintah berperan melalui pemberian bimbingan dan pengarahan yang intensif dan efektif kepada masyarakat. Bimbingan dan pengarahan sangat diperlukan dalam memelihara dinamika. Pemerintah melalui tim penyuluh maupun badan tertentu memberikan bimbingan dan pelatihan kepada masyarakat.

c) Pemerintah sebagai Fasilitator

Peran pemerintah sebagai fasilitator adalah menciptakan kondisi yang kondusif bagi pelaksanaan pembangunan (menjembatani kepentingan berbagai pihak dalam mengoptimalkan pembangunan daerah). Sebagai fasilitator, pemerintah berusaha menciptakan atau menfasilitasi suasana yang tertib, nyaman dan aman, termasuk menfasilitasi tersedianya sarana dan prasarana pembangunan seperti pendampingan dan pendanaan/ permodalan.

d) Pemerintah sebagai katalisator

Pemerintah berposisi sebagai agen yang mempercepat pengembanagan potensi daerah dan negara yang 
kemudian bisa menjadi modal sosial untuk membangun partisispasi.

Menurut Sembiring (2012: 3) fungsi pemerintah negara termasuk pemerintah daerah dimanapun berada, sekurangkurangnya melakukan fungsi pelayanan (services), fungsi pengaturan (regulation), dan fungsi pemberdayaan (empowering), dalam upaya mewujudkan tata kelolah pemerintahan yang baik (good governance).

Menurut Hamdi (2002: 8) fungsi pemerintah yakni melakukan pengaturan dan memberikan pelayanan. Pengaturan dalam arti menegaskan bingkai kesepakatan kehidupan kolektif, agar terdapat kepastian dan perilaku yang memberikan kemanfaatan pada kepentingan umum. Pelayanan terhadap hak-hak masyarakat berisi kegiatan untuk memudahkan masyarakat menikmati hidupnya yang patut atau pantas sesuai dengan nilai-nilai dan martabat kemanusiaannya. Sedangkan pelayanan teradap kewajiban masyarakat berisi kegiatan untuk memampukan masyarakat memahami kepatuhan kolektif yang semestinya dikembangkan. Pelayanan ini kemudiaan sangat berkaitan dengan fungsi pemberdayaan.

Pemberdayaan atau empowerment yang artinya suatu pemberdayaan di dalam meningkatkan potensi manusia agar dapat berorentasi pada pertanggu jawaban kerja yang dilakukan dengan cara yang logis untuk mencapai tujuan dengan melakukan segala bentuk pekerjaan yang berpontesi untuk dikembangkan sesuai kualitas sumber daya manusia yang dapat berprestasi dalam bidang yang ditekuni untuk mencapai tujuan.

Pemberdayaan adalah suatu kegiatan yang berkesinambungan, dinamis, secara sinergis mendorong keterlibatan semua potensi yang ada secara evolutif dengan keterlibatan semua otensi. Dengan ini akan memungkinkan terbentuknya masyarakat madani yang majemuk penuh keseimbangan hak dan kewajiban, saling menghormati tampa ada yang merasa asing dalam komunitasnya. Suhendra (dalam Wrihatnolo $\mathrm{R}$ \& Nugroho R: 2007).

Menurut Sumodingningrat (2004: 41) pemberdayaan tidak bersifat selamanya, melainkan sampai target masyarakat mampu untuk mandiri, dan kemudian dilepas untuk mandiri, meski dari jauh dijaga agar tidak jatuh lagi. Dilihat dari pendapat tersebut berarti pemberdayaan melalui suatu masa proses belajar, hingga mencapai status, mandiri. Meskipun demikian dalam rangka menjaga kemandirian tersebut tetap dilakukan pemeliharaan semangat, kondisi, dan kemampuan secara terus menerus supaya tidak mengalami kemunduran lagi. Tahap-tahap yang harus dilalui tersebut adalah meliputi: (1) Tahap penyadaran dan pembentukan perilaku menuju perilaku sadar dan peduli sehingga merasa membutuhkan peningkatan kapasitas diri; (2) Tahap transformasi kemampuan berupa wawasan pengetahuan, kecakapan keterampilan agar terbuka wawasan dan memberikan keterampilan dasar sehingga dapat mengambil peran di dalam pembangunan; (3) Tahap peningkatan intelektual, kecakapan keterampilan sehingga terbentuklah inisiatif dan kemampuan inovatif untuk menghantarkan pada kemandirian. (Ambar Teguh S, 2004: 82-83).

Tujuan yang ingin dicapai dari pemberdayaan adalah untuk membentuk individu dan masyarakat menjadi mandiri. Kemandirian tersebut meliputi kemandirian berfikir, bertindak dan mengendalikan apa yang mereka lakukan tersebut. Kemandirian masyarakat adalah merupakan suatu kondisi yang dialami oleh masyarakat yang ditandai oleh kemampuan untuk memikirkan, 
memutuskan serta melakukan sesuatu yang dipandang tepat demi mencapai pemecahan masalah-masalah yang dihadapi dengan mempergunakan daya kemampuan yang terdiri atas kemampuan kognitif, konatif, psikomotorik, afektif, dengan mengerahkan sumberdaya yang di miliki oleh lingkungan internal masyarakat tersebut. Terjadinya keberdayaan pada empat aspek tersebut (afektif, kognitif dan psikomotorik) akan dapat memberikan kontribusi pada terciptanya kemandirian masyarakat yang dicitacitakan, dalam masyarakat akan terjadi kecukupan wawasan, yang dilengkapi dengan kecakapan, keterampilan yang memadai, diperkuat oleh rasa memerlukan pembangunan dan perilaku sadar akan kebutuhan tersebut. (Ambar Teguh S, 2004: 80-81).

\section{METODE PENELITIAN}

Jenis penelitian ini adalah penelitian kualitatif. Tipe penelitian adalah deskriptif yang berupaya menggambarkan secara umum tentang fakta yang berhubungan dengan peranan pemerintah daerah dalam pemberdayaan masyarakat petani jagung di Kecamatan Biringbulu Kabupaten Gowa. Hal tersebut dilakukan dengan memahami gejalagejala yang diteliti serta menganalisa apa yang didengar, mempelajari proses penemuan yang terjadi secara alami, mencatat, menafsirkan dan melaporkan serta menarik kesimpulan dari proses tersebut berdasarkan konteks ruang dan waktu serta situsi secara alami.

\section{HASIL DAN PEMBAHASAN}

Salah satu karakteristik dalam pembangunan ekonomi adalah pergeseran jangka panjang populasi dan produksi dari sektor pertanian menjadi sektor industrialisasi. Konsep strategi pembangunan berimbang (balanced growth), yaitu pembangunan di sektor pertanian khususnya petani jagung dan sektor industri secara bersamaan merupakan tujuan pembangunan yang paling ideal. Pada kenyataannya konsep strategi pembangunan berimbang tidak dapat dilakukan oleh negara berkembang, hal ini disebabkan karena sumber daya manusia yang tidak memadai untuk melakukan pembangunan dibidang pertanian dan bidang industri sekaligus.

Pemerintah dalam hal ini Dinas Pertanian Kabupaten Gowa terkait pemberdayaan masyarakat memberikan arahan kepada Kepala Cabang Dinas Pertanian (Kacadis), Koordinator Penyuluh Pertanian Lapangan (PPL) masing-masing setiap Desa/Lelurahan berdasrkan fungsi dan tugasnya setiap saat dapat melakukan pelaksanaan pelatihan terhadap masyarakat petani khususnya petani jagung kapan dan dimana saja melaluai Sekolah Lapangan dalam penerapan Pengelolaan Tanah Terpadu (SL-PTT) dan menerapan paket Teknologi Jagung. Sebagaimana hasil wawancara yang penulis lakukan dengan salah satu aparat Dinas Pertanian Kabupaten Gowa menyatakan bahwa:

"Peran pemerintah daerah dalam hal ini dinas pertanian kabupaten Gowa dalam pemberdayaan petani jagung melaluai bantuan benih, baik bantuan benih langsung Benih Unggul ( $B L B U$ ) maupun benih bersupsidi dan memberikan arahan-arahan tentang pertanian tersebut, bagaimana pemilihan bibit unggul, cara memelihara tanaman jagung dan mengelolah tanah agar tetap subur dan bagaimana cara meningkatkan hasil panen agar lebih banyak dari musim kemusim". (Wawancara MS). 
Dalam pemberdayaan masyarakat petani jagung para aparat pemerintah dinas pertanian memberikan bantuan benih, baik bantuan benih langsung benih unggul (BLBU) arahan-arahan kepada Kepala cabang Dinas Pertanian di setiap Kecamatan. Kepala cabang Dinas Pertanian menyampaikan arahan kepada penyuluh pertanian lapangan di setiap Desa maupun Kelurahan.

Selain fungsi pemerintah daerah yang dijelaskan di atas, pemerintah daerah masih mempunyai peranan yang lebih penting terhadap kemajuan dan perkembangan wilayah yang dipimpinnya yaitu melaksanakan pembinaan terhadap masyarakat dalam meningkatkan peran serta mereka terhadap pengembangan pembangunan khususnya di bidang pertanian tanaman jagung. Berdasarkan hasil penelitian maka dapat dideskripsikan tentang peran pemerintah daerah dalam pemberdayaan masyarakat petani jagung yang secara garis besar mencakup hal-hal sebagai berikut:

\section{Peran Pemerintah Daerah Dalam Pendidikan dan Pelatihan}

Peran pemerintah dalam pendidikan dan pelatihan adalah menggerakan partisipasi multipihak dalam proses pembangunan. Dimana melibatkan 3 pihak yaitu melibatkan pemerintah, swasta, dan warga masyarakat. Sebagai pemerintah berperan memberikan pelaksanaan melalui pemberian bimbingan dan pengarahan yang intensif dan efektif kepada masyarakat.

Dalam rangka pelaksanaan pelatihan, pembimbingan dan pengarahan yang dilakukan pemerintah di Kecamatan Biringbulu untuk meningkatkan keterampilan para petani maka dilakukanlah penyuluhan yaitu melalui pemberian pedoman, bimbingan, pelatihan, arahan, dan supervise di mana pun dan kapan saja.

Peran pemerintah daerah melalui Kepala cabang dinas pertanian sebagai memberikan pelaksanaan pelatihan dalam hal ini pemberian penyuluhan pertanian lapangan di Kecamatan Biringbulu diharapkan dapat menimbulkan kesadaran dan partisipasi warga yang menjadi kunci keberhasilan pembangunan daerah tersebut termasuk pembagunan pada sektor pertanian khususnya petani jagung. Untuk menumbuhkan kesadaran masyarakat akan pentingnya usaha-usaha pembangunan dibidang pertanian sebagai sarana untuk memperbaiki kondisi sosial dan ekonomi masyarakat agar lebih sejahtera maka dibutuhkan peran pemerintah secara maksimal, sehingga dalam meningkatkan partisipasi dan kesadaran masyarakat dalam pembangunan banyak tergantung pada kemampuan pemimpin yang ada di daerah tersebut.

Kecamatan Biringbulu dalam pelaksanaan pendidikan dan pelatihan memberikan penyuluhan terhadap masyarakat yaitu dengan cara mengumpulkan kelompok tani dan masyarakat di tiap Desa dan Kelurahan. Untuk memberikan pengertian tentang kegiatan-kegiatan apa saja yang perlu dilaksanakan dan bagaimana pelaksanaannya di lapangan. Seperti bagaimana pemeilihan bibit atau benih unggul yang cocok dengan cuaca, iklim, dan ph tanah. Dan bagaimana memelihara Tanaman Jagung.Apabila masyarakat telah memahami dan mengerti tentang hal tersebut maka pemerintah tinggal menggerakkan dan memberikan bimbingan bagaimana sistem pengelolaan pertanian khususnya jagung.

Pemerintah daerah dalam hal in dinas pertanian Kabupaten Gowa melalui Kepala cabang dinas pertanian 
memberikan tugas kepada penyuluh pertanian lapangan (PPL) dan lembagalembaga pertanian agar berperan aktif. Pemberdayaan masyarakat petani jagung dalam bidang pertanian memiliki makna meningkatkan kualitas kehidupan sosial ekonomi masyarakat yang tercermin peningkatan pendapatan dan kesejahteraan masyarakat. Sehingga bentuk peran pemerintah Kecamatan Biringbulu sebagai memberikan pelaksanaan pelatihan meliputi penyuluhan, belajar, uji coba varietas, sekolah lapang, dan pengelolaan tanaman (SLPTT). Sebagaimana hasil wawancara yang penulis lakukan dengan salah satu aparat Kecamatan Biringbulu yang menyatakan bahwa:

"Peran pemerintah kecamatan Biringbulu dalam hal ini pemberdayaan masyarakat petani jagung melalui Kepala cabang dinas pertanian memberikan tugas kepada lembaga-lembaga pertanian agar berperan aktif dan juga memberikan tugas kepada para Penyuluh pertanian lapangan (PPL) di masing-masing desa maupun kelurahan sesuai tugas dan tanggu jawabnya, tentang bagaimana agar para petani dapat meningkat produksi hasil jagung". (Wawancara MB).

Pemberdayaan masyarakat petani jagung di Kecamatan Biringbulu para aparat pemerintah melalui Kepala Cabang Dinas Pertanian memberikan tugas kepada Lembaga-lembaga agar berperan aktif dan memberikan tugas kepada Pelaksana Penyuluh Pertanian (PPL) yang harus terjung langsung untuk memberikan arahan-arahan kepada masyarakat baik dalam bentuk penyuluhan maupun dalam bentuk belajar-belajar di lapangan kapan pun dan dimana saja.
Kelompok tani Desa Berutallasa. Ia menuturkan apa yang ia rasakan bahwa setiap bimbingan dan arahan yang diberikan para aparat pemerintah Pelaksana Penyuluh Lapangan (PPL) itu diterima dengan sangat antusias dan mengharapkan para penyuluh lapangan merangkul semua kelompok tani di desa maupun kelurahan dan masyarakat petani lain.

Pemberdayaan masyarakat petani jagung melalui pelaksanaan pelatihan yang diberikan aparat pemerintah melalui penyuluh pertanian lapangan itu sangat berarti bagi masyarakat petani jagung khususnya dalam meningkatkan keterampilan para petani dalam mengelolah pertaniannya, dengan melalui penyuluh lapangan masyarakat akan lebih mengerti tentang cara-cara pengolahan tanah yang baik, pengairan yang teratur, pemilihan bibit unggul, pemupukan berimbang, pengendalian hama tanaman, dan pengolahan pasca panen. Karena peran pemerintah melaluai penyuluh lapangan sangat menentukan kemajuan pertanian jagung di Kecamatan Biringbulu.

\section{Peran Pemerintah Daerah Dalam Bantuan Modal Usaha}

Peran pemerintah dalam bantuan modal usaha adalah menciptakan kondisi yang kondusif bagi pelaksanaan pembangunan. Pemerintah Kecamatan Biringbulu melalui Kepala cabang Dinas Pertanian berusaha menfasilitasi para petani agar hasil produksi pertanian dapat meningkat. Peningkatan hasil adalah hal yang selalu diharapkan dalam kegiatan produksi pertanian.Berbicara suatu lokasi pertanian yang tetap maka upaya ini dekat dengan aspek intensifikasi pertanian. Intensifikasi pertanian adalah kegiatan peningkatan Kuantitas dan kualitas bertani dengan berbagai sarana dan prasarana untuk 
meningkatkan hasil pertanian pada suatu daerah.

Pemerintah Kecamatan Biringbulu melalui kepala cabang dinas pertanian dalam upaya pemberian bantuan modal usaha berupa bantuan benih baik bantuan langsung (BLBU) maupun bantuan benih bersupsidi dan bantuan modal usaha yang di berikan kepada kelompok tani melalui gabungan kelompok tani (Gapoktan) juga bantuan simpan pinjam dengan sumber anggran Perusahaan Pemberdayaan Agrobisnis Pedesaan (PUAP).

Masyarakat petani jagung telah terbantu oleh pemerintah daerah dalam hal ini dinas pertanian melalui kepada cabang dinas pertanian telah memberikan bantuan modal berupa bibit, pupuk, pestisida sampai dengan perbaikan prasarana, akan tetapi belum optimal dilaksanakan karena masih banyak kelompok tani yang belum mendapatkan bantuan di tiap desa maupun kelurahan di Kecamatan Biringbulu.

Setiap aktivitas tersebut tidaklah terlepas dari bantuan modal pertanian untuk memudahkan jalannya proses produksi sampai pada pasca produksi. Bantuan modal yang dimaksud adalah bantuan dana dan alat mesin pertanian. Dengan penggunaan dan dan bantuan alat mesin yang tepat diharapkan terjadinya efektivitas dan efisiensi proses produksi sampai pada pasca produksi sehingga hasil pertanian pun dapat meningkat produksinya. Dengan bantuan modal dan bantuan alat mesin maka kegiatan dalam bertani akan semakin cepat. Adapun proses pemberdayaan masyarakat petani jagung sebagai berikut:

a. Jumlah Kecukupan

Dalam jumlah kecukupan bantuan modal yang di berikan pemerintah kepada masyarakat petani jagung sebenarnya belum cukup di kareanakan secara historis Kecamatan Biringbulu adalah adalah hasil pemekaran dari Kecamatan Tompobulu. Di mana mayoritas penduduknya $100 \%$ beragama islam dengan penhasilan bertani 73\% petani jagung. Dari sembilan desa dan dua Kelurahan.

Masyarakat petani jagung dari jumlah kecukupan sebenarnya belum mencukupi dari Sembilan Desa dua Kelurahan di karenakan dari dinas pertanian memiliki target dari delapan belas kecamatan khusunya Kecamatan Biringbulu.

b. Mudah atau Sulit

Peran pemerintah daerah dalam hal ini dinas pertanian melalui kepala cabang dinas (Kacadis) Kecamatan Biringbulu memberikan bantuan berupa bibit, pupuk,pestisida dan sampai dengan pemberian bantuan modal simpan pinjam melalui penyuluh pertanian lapangan (PPL) di berikan kepada gabungan kelompok tani (Gapoktan) dari anggaran Perusahaan Pemberdayaan Agribisnis Pedesaan (PUAP). Sebagaimana dengan hasil wawancara penulis melakukan dengan salah satu aparat dinas pertanian Kabupaten Gowa yang menyatakan bahwa :

"Dalam pemberian bantuan modal kami biasanya tidak mendapatkan kesulitan karena di setiap Kecamatan ada penyuluh pertanian lapangan yang menberikan bantuan modal kepada kelompok tani yang anggarannya dari perusahaan pemberdayaan agribisnis pedesaan (PUAP). Yang kami dapatkan hanyalah kemudahan di karenakan ini kewajiban kami selaku aparat dinas pertanian". (Wawancara MS).

Peran pemerintah daerah dalam hal pemberdayaan masyarakat petani jagung sangatlah mudah di karenakan ada 
masing-masing anggaranya tinggal di laksanakan oleh penyuluh pertanian lapangan.

\section{c. Waktu}

Waktu pelaksanaan bantuan modal itu adalah setiap memasuki musim tanam yang dilaksanakan dalam satu tahun masa tanaman jagung. Karena masyarakat sangat menbutuhkan bantuan dana untuk produksi sampai pasca produksi. Secara rincian waktu adalah seluruh rangkaian saat ketika proses, perbuatan atau berada atau berlangsung. Dalam hal ini skala waktu merupakan interval antara dua buah keadaan/kejadian, atau biasa merupakan lama berlangsungnya suatu kejadian. Waktu pelaksanaa bantuan modal di berikan kepada masyarakat petani jagung melalui gabungan kelompok tani (Gapoktan) setiap ada bantuan langsung dari dinaspertanian di berikan kepada penyuluh pertanian lapangan kepada setiap kelompok tani. Sebagaimana hasil wawancara dengan yang penulis lakukan dengan Kepala Cabang Dinas Pertanian. yang menyatakan bahwa:

"Waktu pelaksanaan Bantuan modal yang kami berikan langsung kami berikan melalaui setiap gabungan kelompok tani (Gapoktan) ketika pada saat mendapatkan bantuan dari dinas pertanian kecamatan biringbulu". (Wawancara $\mathrm{MH}$ ).

Dalam pemberdayaan masyarakat petani jagung dalam waktu pelaksanaannya langsung diberikan kepada gabungan kelompok tani (Gapoktan) .

\section{d. Efektif}

Efektif adalah pencapaian tujuan secara tepat atau memilih tujuan-tujuan yang tepat dari serangkaian alternatif atau pilihan cara dan menetukan pilihan dari beberapa pilihan lainnya. Efektif juga bisa di artikan pengukuran keberhasilan dari pencapaian tujuan-tujuan yang telah di tentukan. Seperti halnya dalam peran pemerintah daerah dalam pendistribusian bantuan pupuk kepada kelompok tani di setiap desa maupun kelurahan yang ada di Kecamatan Biringbulu. Dalam pemberdayaan masyarakat petani jagung di lihat dari segi efektifnya sudah dilaksanakan akan tetapi belum efektif pencapaian tujuan kepada masyarkat.

\section{Peran Pemerintah Daerah Dalam Distribusi Bantuan Pupuk}

Peran pemerintah Kecamatan Biringbulu melalui kepala cabang dinas pertanian dalam rangkah pemberdayaan masyarakat petani jagung salah satu peran pemerintah yaitu pendistribusian pupuk, merupakan bahan yang sulit dipisahkan dari kebutuhan petani jagung, dalam penyaluran bantuan kepada masyarakat melalui penyuluh pertanian lapangan kepada gabungan kelompok tani (Gapoktan) keseluruh desa Maupun kelurahan. Akan tetapi dalam penyaluran bantuan secara bertahap agar dapat merata kepada setiap Desa maupun Kelurahan yang ada di Kecamatan Biringbulu. Sebagaimana hasil wawancara dengan Kepala Cabang Dinas Pertanian yang menyatakan bahwa :

"Dalam pendistribusian Bantuan pupuk, saya selaku perpanjangan tangan dinas pertanian memberikan bantuan berupa pupuk kepada msayarakat petani jagung sesuai kebutuhannya akan tetapi tidak semua kelompok tani mendapatkan bantuan dikarena kelompok tani yang mendapatkan tahun ini tidak mendapatkankan lagi tahun depan agar dapat merata kepada enam ratus enam puluh kelompok tani yang ada di Kecamatan biringbulu". (Wawancara $M H$ ) . 
Peran pemerintah daerah dalam pendistribusian bantuan pupuk sudah di laksanakan akan tetapi belum maksimal, Dapat di lihat dari segi sebagi berikut:

a. Jumlah Kecukupan

Dalam jumlah kecukupan pendistribusian bantuan pupuk yang di berikan pemerintah kepada masyarakat petani jagung sebenarnya belum cukup di kareanakan Kecamatan Biringbulu memiliki jumlah desa maupun kelurahan 11 (sebelas) desa dan kelurahan (Desa Berutallasa, Kelurahan Lauwa, Desa Julukanaya, Kelurahan Tonrorita, Desa Pencong, Taring, Parangloe,Lengbangloe, Batu Malongro, Baturappe, dan Desa Borimasunggu. Yang memiliki jumlah penduduk laki-laki sebanyak 15,961 jiwa dan perempuan sebanyak 16,712 jiwa dan Jumlah kelompok tani yang ada di Kecamatan Biringbulu sebanyak 460 (Empat ratus enam puluh) yang hanya 2$5 \%$ kelompok tani mendapatkan. Sebagaimana hasil wawancara dengan penulis lakukan dengan salah satu kelompok tani di desa Berutallasayang menyatakan bahwa :

"Pemberian Bantuan pupuk oleh pemerintah memang sudah dilakukan akan tetapi belum sepenuhnya merata kepada, kami biasanya mendapatkan tahun ini, tahun depan tidak mendapatkan lagi". (Wawancara AH)

Peran pemerintah dalam pendistribusian bantuan pupuk sudah berjalan tapi belum maksimal.

b. Kendala

Peran pemerintah daerah dalam pendistribusian bantuan pupuk kepada masyarakat petani jagung yang ada di Kecamatan Biringbulu melalui Penyuluh pertanian lapangan yang di berikan langsung kepada kelompok tani. Dalam pendistribusian pupuk biasanya mengalami kendala keterbatasan personil dalam penstribusian bantuan pupuk kepada masyarakat petani jagung di setiap desa maupun kelurahan dan bantuan pun sesuai dengan target di setiap Kecamatan yang ada di Kabupaten Gowa. Bantuan pupuk di berikan pemerintah kepada kelompok tani sudah berjalan akan tetapi belum maksimal.

c. Ketepatan

Ketepatan adalah kemampuan seseorang untuk mengarahkan sesuatu gerak kesuatu serangan dengan tujuannya. Seperti halnya dalam peran pemerintah daerah dalam mengarahkan kepada setiap penyuluh pertanian lapangan dalam pembagian batuan pupuk kepada kelompok tani yang ada di kecamatan Biringbulu agar produksi jagung dapat meningkat. Sebagaimana hasil wawancara yang penulis lakukan dengan salah satu aparat dinas pertanian Kabupaten Gowa yang menyatakan bahwa :

"Peran pemerintah daerah dalam hal ini dinas pertanian kabupaten Gowa dalam hal ketepan pemberian bantuan pupuk kepada penyuluh pertanian lapangan (PPL) di setiap kecamatan yang ada di Kabupaten Gowa terutama Kecamatan Biringbulu sudah tepat. Dalam hal pemberdayaan petani jagung melaluai bantuan pupuk agar kiranya produksi tanaman jagung dapat meningkat ". (Wawancar MS).

Dalam pendistribusian pupuk sudah berjalan akan tetapi belum maksimal di karenakan masih ada kelompok tani yang mendapatkan bantuan pupuk.

\section{E. PENUTUP}

Berdasarkan uraian hasil penelitian yang telah dibahas dalam bab sebelumnya, maka pada bagian ini dapat ditarik beberapa kesimpulan sebagai berikut: (1) Peran pemerintah daerah dalam pemberdayaan masyarakat petani 
jagung dalam hal ini dinas pertanian kab. Gowa sudah berjalan dengan baik; (2) Peran pemerintah daerah dalam hal ini kepala cabang dinas pertanian kecamatan Biringbulu melalui Penyuluh lapangan sudah melaksanakan pelatihan petani jagung sudah berjalan dengan baik, akan tetapi belum maksimal di karenakan masih banyak kelompok tani belum mendapatkan pelatihan; (3) Peran pemerintah daerah dalam hal ini Dinas pertanian sudah memberikan bantuan modal berupa bibit maupun pupuk dan bantuan simpan pinjam sudah berjalan dengan baik akan tetapi tidak semua petani jagung mendapatkan bantuan modal; (4) Peran pemerintah daerah dalam pendistribusian bantuan pupuk sudah dilakukan akan tetapi belum maksimal dilakukan.

Upaya untuk mengoptimalkan fungsi pemerintah terhadap pengembangan masyarakat dari hasil temuan penelitian dapat di rekomondasikan saran untuk peningkatannya sebagai berikut: (1) Pemerintah Daerah harus lebih banyak menyiapkan tenaga penyuluh yang secukupnya agar masyarakat benarbenar bisa mengetahui tentang pengajaran-pengajaran penyuluhan yang telah di berikan dan tim peyuluh juga bisa bekerja secara optimal kepada para kelompok tani di setiap desa maupun kelurahan; (2) Pemerintah harus lebih memperhatikan danmewujudkan pasilitas terutama Bantuan modal kepada kelompok tani agar produksi pertanian dapat meningkat; (3) Pemerintah juga harus lebih memperhatikan dan mewujudkan fasilitas pertanian terutama bantuan pupuk kepada kelompok tani agar hasil pertanian dapat meningkat dari tahun ke tahun.

DAFTAR PUSTAKA

Arif., 2012. Peran dan fungsi pemerintah, pada $\quad 12$ februari 2012 http://arifgii.blogspot.com/2012/1

2/peran-dan-fungsi-

pemerintahan.html.di ambil tanggal 15 januari 2014.

Ambar Teguh S. (2004). Kemitraan dan Model-model Pemberdayaan.

Yogyakarta: Gava Media.

Faturochman, dkk. 2007. Membangun Gerakan Penanggulangan

Kemiskinan Melalui Pemberdayaan Masyarakat. Yogyakarta: Pusat Studi Kependudukan dan Kebijakan Universitas Gadjah Mada

Hamdi, Muchlis., 2002. Bunga Rampai Pemerintahan, Bandung: Yarsif Watampone.

Istianto, Bambang., 2009. Manejemen Pemerintahan Dalam Prespektif Pelayanan Publik, Jakarta: Mitra Wacana Media.

Jasmay, Owin, 2004. Keadilan, Pemberdayaan \& Penanggulangan Kemiskinan, Bandung: Blantika.

Syafiie, Inu Kencana. 2002. Sistem Pemerintahan Indonesia, Jakarta: Rineka Cipta.

2005. Pengantar Ilmu Pemerintahan, Bandung: Refika Aditama.

2011. Manajemen Ilmu Pemerintahan, Bandung: Refika Aditama.

Korten., C David., 2002. Menuju Abad Ke21, Tindakan sukarela dan agenda global, Jakarta: Yayasan Obor Indonesia.

Labolo, Muhadam., 2011. Memahami Ilmu Pemerintahan, Jakarta: Rajawali Pers. 
Moleong, Jexy J., 2005. Metodologi Penelitian Kualitatif, Bandung: Rosda.

Marwansyah.2010.manejemen Sumber Daya Manusia edisi kedua Bandung: alfabeta.

Phahasta, Arief. 2009. Agribisnis Jagung. Cv. Pustaka Grafika. Wandi.

Rahmawati, Ike Kusdiyah., 2008. Manajemen Sumber Daya Manusia, Yogyakarta: Andi Offset.

Sembiring, Masana. 2012. Budaya Dan Kinerja Organisasi, Bandung: Fokusmedia.

Sulistyani, Ambar Teguh dan Rosidah, 2003. Manejemen Sumber Daya Manusia, cetakan pertama. Yogyakarta: Graha ilmu.

Sumodingningrat (2004). Kemitraan dan Model-model Pemberdayaan. Yogyakarta: Gava Media.

Wrihatnoholo, Nugroho. 2007. Manejemen Pemberdayaan. Elexm Media: Jakarta.

Verawati, Tuti A., 2003. Peran Pemerintah Dalam Pemberdayaan Masyarakat Nelayan Di Kecamatan Tempe Kabupaten Wajo. Makassar: Universitas 45 Makassar

\section{Dokumen}

Undang-undang Nomor 19 Tahun 2013

Tentang Pemberdayaan Petani. 